\title{
SKRINING AKTIVITAS FRAKSI ETILASETAT DAUN NUSA INDAH (Mussaenda philippica A. Rich)
}

\author{
Annisa Mercury*, Risna Agustina, Laode Rijai \\ Laboratorium Penelitian dan Pengembangan Kefarmasian FARMAKA TROPIS \\ Fakultas Farmasi, Universitas Mulawarman, Samarinda, Kalimantan Timur \\ *email : annisamercury18@gmail.com
}

\begin{abstract}
ABSTRAK
Nusa Indah (Mussaenda philippica A. Rich) merupakan tanaman dengan kelopak daun berwarna putih. Masyarakat menggunakan daun Nusa Indah sebagai obat disentri dan diare akut. Penelitian ini bertujuan untuk mencari toksisitas dan potensi antioksidan fraksi etilasetat daun Nusa Indah. Uji toksisitas fraksi etilasetat menggunakan larva udang Artemia salina Leach (Brine Shrimp Lethality Test, BSLT). Aktivitas antioksidan menggunakan metode peredaman radikal bebas 1,1 difenil-2-pikrilhidrazil (DPPH). Hasil BSLT menunjukkan nilai $\mathrm{LC}_{50}$ fraksi etilasetat daun Nusa Indah adalah 37, $15 \mathrm{ppm}$. Nilai IC50 fraksi etilasetat daun Nusa Indah adalah 8,13 ppm.
\end{abstract}

Kata kunci: daun, Mussaenda philippica A. Rich, antioksidan, toksisitas

\begin{abstract}
Nusa Indah (Mussaenda philippica A. Rich) is a plant with white sepals. People use Nusa Indah leaves as a cure dysentery and acute diarrhea. Research has been conducted with a purpose to find out toxicity and the potential of the fraction ethylacetate of leaves Nusa Indah as an antioxidant. The toxicity test of fraction ethylacetate against brine shrimp Artemia salina Leach (Brine Shrimp Lethality Test, BSLT). It was also evaluated for antioxidant activity using reduction free radical 1,1-diphenyl-2-picrilhydrazil (DPPH) method. The result of BSLT showed that $L C_{50}$ (Lethality Concentration 50) ethylacetate fraction of leaves Nusa Indah was 37,15 ppm. The result of DPPH tests showed that IC 50 (Inhibition Concentration 50) of ethylacetate fraction of leaves Nusa Indah was 8,13 ppm.
\end{abstract}

Keywords : leaves, Mussaenda philippica A. Rich, antioxidant, toxicity

\section{PENDAHULUAN}

Menurut Hariana (2013) masyarakat menggunakan daun Nusa Indah sebagai obat disentri dan diare akut. Uji toksisitas pada ekstrak tanaman biasanya dilakukan untuk mengetahui tingkat keamanan suatu ekstrak. Dimana pengujian toksisitas biasanya dengan menggunakan hewan uji. Salah satu hewan uji yang sesuai adalah Brine Shrimp (udang laut) A. salina Leach [8]. Metode BSLT adalah salah satu cara yang digunakan untuk mengetahui kemampuan toksik terhadap sel (sitotoksik) dari suatu senyawa, yang dihasilkan oleh ekstrak tanaman dengan menggunakan larva udang Artemia salina Leach sebagai bioindikator (Kanwar, 2007). BSLT lazim digunakan karena lebih murah, mudah, cepat dan hasilnya 
akurat. Selain itu, metode ini telah terbukti memiliki hasil yang berkorelasi dengan kemampuan sitotoksik senyawa anti kanker.

Sebagian besar penyakit degeneratif diawali oleh reaksi oksidasi yang berlebihan di dalam tubuh. Reaksi ini memicu terbentuknya radikal bebas yang sangat aktif, yang dapat merusak struktur serta fungsi sel. Namun, reaktivitas radikal bebas tersebut dapat dihambat oleh sistem antioksidan [9].

Antioksidan adalah zat yang dapat menunda, memperlambat dan mencegah terjadinya proses oksidasi. Antioksidan sangat bermanfaat bagi kesehatan dan berperan penting untuk mempertahankan mutu produk pangan. Manfaat antioksidan bagi kesehatan dan kecantikan, misalnya untuk mencegah penyakit kanker dan tumor, penyempitan pembuluh darah, penuaan dini, dan lain-lain. Dalam produk pangan, antioksidan dapat digunakan untuk mencegah terjadinya proses oksidasi yang dapat menyebabkan kerusakan, seperti ketengikan, perubahan warna dan aroma, serta kerusakan fisik lainnya.

Banyak penelitian telah membuktikan manfaat mengkonsumi tanaman yang berkhasiat antioksidan, seperti dapat menurunkan resiko penyakit jantung, kanker, katarak dan penyakit degeneratif lain.

Berdasarkan uraian di atas, dilakukan analisis untuk menentukan golongan senyawa metabolit sekunder, uji toksisitas serta uji aktivitas antioksidan dengan metode peredaman radikal 2,2-diphenyl-1-picrylhidrazyl (DPPH) dari daun Nusa Indah.

\section{METODE PENELITIAN}

\section{Bahan}

Simplisia daun Nusa Indah (Mussaenda philippica A. Rich), etanol, n-heksana, etil asetat, n-butanol, metanol pro analisis, air suling, pereaksi Dragendroff, pereaksi Mayer, asam klorida pekat, serbuk magnesium, besi (III) klorida, asam asetat glasial asam sulfat pekat, kalium hidroksida, larva udang Artemia salina Leach, air laut dan pereaksi DPPH (1,1-diphenyl-2-picrylhydrazyl).

\section{Peralatan}

Seperangkat alat maserasi, rotary evaporator (Büchi rotavapor $R$-200), timbangan analitik (Precisa XB 220A), tabung reaksi (Pyrex), tangas air (waterbath), labu ukur gelap (Pyrex), pipet tetes (Pyrex), corong (Pyrex), mikropipet (Boeco), batang pengaduk, kertas Whatmann, aluminium foil, gelas kimia (Pyrex), labu ukur (Pyrex), vial, cawan penguap, kertas saring, corong pisah (Pyrex), wadah penetas, dan lampu 60 watt, tabung reaksi bertutup (Pyrex), mikro pipet, vortex mixer $\left(H\right.$-VM-400), kuvet $\left(\right.$ Brand $\left.^{\circledR}\right)$, spektrofotometer UV-Vis (Spectrophotometer Double Beam Halo DB-209 Dynamica).

\section{Prosedur}

\section{Penyiapan Sampel}

Daun Nusa Indah diperoleh dari Tenggarong Sebrang, Kabupaten Kutai Kertanegara, Kalimantan Timur. Daun Nusa Indah yang diambil adalah daun yang masih utuh, hijau dan segar kemudian dikumpulkan serta dipisahkan dari pengotor lain seperti bagian bukan daun atau bagian tanaman yang rusak lalu dicuci bersih, selanjutnya sampel dipotong-potong kemudian dibuat simplisia dengan cara dikeringkan tanpa terkena sinar matahari secara langsung. 


\section{Ekstraksi dan Fraksinasi Sampel}

Simplisia daun Nusa Indah yang telah dihaluskan dimasukkan kedalam bejana maserasi. Pelarut etanol ditambahkan sambil diaduk hingga seluruh serbuk kasar terbasahi merata dengan pelarut. Perendaman dengan menggunakan pelarut etanol selama 48 jam dengan sesekali dilakukan pengadukan. Pelarut hasil ekstraksi disaring dan ditampung kedalam wadah. Prosedur diulangi hingga pelarut berwarna bening. Cairan hasil ekstraksi yang diperoleh selanjutnya dipekatkan dengan cara diuapkan dengan menggunakan rotary evaporator sampai seluruh pelarutnya menguap sehingga didapatkan ekstrak kental.

Proses fraksinasi dilakukan dengen cara bertingkat dengan metode fraksinasi caircair. Fraksinasi dibuat dari fraksi n-heksana, etil asetat hingga $n$-butanol. Ekstrak kasar etanol ditimbang 10 gram kemudian dilarutkan air suling sebanyak $100 \mathrm{~mL}$. Selanjutnya dimasukkan kedalam corong pisah, ditambahkan $100 \mathrm{~mL}$ pelarut n-heksana dan dilakukan pengojogkan. Setelah itu didiamkan sehingga terbentuk 2 (dua) lapisan. Lapisan bawah diambil untuk dilanjutkan fraksinasi selanjutnya. Dalam setiap pelarut organik dilakukan pengulangan hingga lapisan atas terlihat bening. Lapisan atas hasil fraksinasi dikeringkan atau diuapkan sehingga diperoleh ekstrak kering atau ekstrak kental. Fraksi etil asetat yang diperoleh diuji fitokimia, uji toksisitas dan aktivitas antioksidannya.

\section{Uji Metabolit Sekunder}

\section{a. Uji Alkaloid}

Sebanyak $2 \mathrm{~mL}$ fraksi etilasetat diuapkan di atas cawan porselin. Residu yang dihasilkan kemudian ditambahkan dengan $5 \mathrm{~mL} \mathrm{HCl} 2 \mathrm{M}$. Larutan yang diperoleh dibagi ke dalam 3 tabung reaksi. Tabung pertama berfungsi sebagai blanko, ditambahkan dengan 3 tetes $\mathrm{HCl} 2 \mathrm{M}$. Tabung kedua ditambahkan 3 tetes pereaksi Dragendorff dan tabung ketiga ditambahkan 3 tetes pereaksi Mayer. Fraksi etilasetat positif mengandung alkaloid jika pada pereaksi Dragendorff akan terbentuk endapan berwarna jingga sedangkan pereaksi Mayer akan terbentuk endapan kuning [2].

\section{b. Uji Fenol}

Fraksi etilasetat sampel sebanyak $1 \mathrm{~mL}$ dimasukkan ke dalam tabung reaksi untuk dilakukan pengujian fenolik dengan cara fraksi etilasetat ditambahkan pereaksi $\mathrm{FeCl} 31 \%$. Fraksi etilasetat positif mengandung senyawa fenolik jika terjadi warna hitam [2].

\section{c. Uji Flavonoid}

Sebanyak $2 \mathrm{~mL}$ fraksi etilasetat ditambahkan dengan air panas secukupnya, kemudian dididihkan selama 5 menit lalu disaring. Filtrat sebanyak $5 \mathrm{~mL}$ ditambahkan 0,05 mg serbuk $\mathrm{Mg}$ dan $1 \mathrm{~mL} \mathrm{HCl}$ pekat, kemudian dikocok kuatkuat. Fraksi etilasetat positif mengandung flavonoid jika terbentuknya warna merah, kuning atau jingga [2].

\section{d. Uji Tanin}

Sebanyak $1 \mathrm{~mL}$ fraksi etilasetat ditambahkan dengan beberapa tetes larutan besi(III) klorida $10 \%$. Fraksi etilasetat positif mengandung tanin jika terbentuk warna biru tua atau hitam kehijauan [2].

\section{e. Uji Steroid}

Sebanyak $2 \mathrm{~mL}$ fraksi etilasetat ditambahkan $\mathrm{CH}_{3} \mathrm{COOH}$ glasial sebanyak 10 tetes dan $\mathrm{H}_{2} \mathrm{SO}_{4}$ pekat sebanyak 2 tetes. Larutan dikocok perlahan dan dibiarkan selama beberapa menit. Fraksi etilasetat positif mengandung adanya steroid ditunjukan oleh warna biru atau hijau, sedangkan triterpenoid memberikan warna merah atau ungu [2]. 


\section{f. Uji Saponin}

Sebanyak 2-3 mL fraksi etilasetat dimasukkan ke dalam tabung reaksi, kemudian ditambahkan $10 \mathrm{~mL}$ air panas lalu didinginkan, kemudian dikocok kuat-kuat selama 10 detik lalu ditambahkan 1 tetes $\mathrm{HCl} 2 \mathrm{~N}$. Fraksi etilasetat positif mengandung saponin jika terbentuk buih yang stabil setinggi $1-10 \mathrm{~cm}$ selama tidak kurang dari 10 menit [2].

\section{Uji Toksisitas}

\section{a. Penyiapan Bioindikator Uji}

Sekitar $200 \mathrm{mg}$ telur A. salina ditetaskan dalam wadah penetas yang telah disiapkan pada temperatur yang sesuai dengan temperatur tetas yaitu dengan pemberian pemanasan dengan cahaya lampu pijar 5 watt. Penetasan berlangsung 72 jam, dan mulai 48 jam telah diperoleh larva yang siap untuk diuji.

\section{b. Pengujian Toksisitas}

Pengujian toksisitas dilakukan dengan cara 10 ekor Artemia salina Leach dimasukkan kedalam masing-masing vial yang berisi fraksi etilasetat dari masing-masing konsentrasi uji, kemudian kedalam vial-vial tersebut dimasukkan 1 tetes makanan larva yaitu ragi sebanyak $3 \mathrm{mg} / 5 \mathrm{~mL}$. Vial-vial tersebut ditutup menggunakan almunium foil, kemudian diletakkan dibawah penerangan selama 24 jam, kemudian diamati jumlah larva yang mati pada masingmasing vial. Lalu dihitung $\mathrm{LC}_{50}$ dengan menggunakan metode Reed and Muench.

\section{Aktivitas Antioksidan}

Pengujian aktivitas antioksidan dilakukan dengan cara mengambil $2 \mathrm{~mL}$ fraksi etilasetat dari masing-masing konsentrasi uji, kemudian ditambahkan dengan 2 mL larutan DPPH 40 ppm. Selanjutnya campuran larutan ini di homogenkan dengan menggunakan vorteks dan dibiarkan ditempat gelap pada suhu kamar selama 30 menit. Kemudian larutan diukur absorbansinya dengan menggunakan Spktrofotometer UV-Visible pada panjang gelombang maksimum $(517 \mathrm{~nm})$. Dilakukan juga pengukuran terhadap blanko yang terdiri atas $2 \mathrm{~mL}$ DPPH 40 ppm dan $2 \mathrm{~mL}$ metanol pro analisis. Dari hasil pengukuran absorbansi tersebut selanjutnya dihitung persen aktivitas antioksidan. Lalu dihitung $\mathrm{IC}_{50}$ dengan menggunakan persamaan regresi linear.

\section{HASIL DAN PEMBAHASAN}

Tabel 1. Metabolit sekunder fraksi etil asetat daun Nusa Indah

\begin{tabular}{lcl}
\hline Metabolit Sekunder & Fraksi Etil Asetat & \multicolumn{1}{c}{ Keterangan } \\
\hline Alkaloid & - & $\begin{array}{l}\text { Tidak terbentuk endapan berwarna jingga } \\
\text { (Dragendorff) dan endapan kuning (Mayer) }\end{array}$ \\
Flavanoid & & $\begin{array}{l}\text { tidak terbentuk warna merah, kuning atau } \\
\text { jingga }\end{array}$ \\
Fenolik & - & Terbentuk warna hitam \\
Tanin & + & Terbentuk warna hitam kehijauan \\
Saponin & + & Tidak terbentuk buih \\
Steroid & - & Terbentuk warna biru \\
Triterpenoid & + & Tidak warna merah atau ungu \\
\hline
\end{tabular}




\section{Skirining fitokimia}

Skirining fitokimia merupakan tahap pendahuluan dalam suatu penelitian fitokimia yang bertujuan memberi gambaran tentang golongan senyawa yang terkandung dalam tanaman yang diteliti. Informasi kandungan senyawa metabolit sekunder diperlukan karena senyawa aktif yang terdapat dalam tanaman dapat bersifat toksik. Hasil identifikasi metabolit sekunder fraksi etil asetat daun Nusa Indah diperoleh hasil positif yaitu golongan senyawa fenol, tanin dan steroid. Hasil uji metabolit sekunder dapat dilihat pada Tabel 1.

\section{Toksisitas}

Pengujian toksisitas merupakan pengujian awal untuk mengetahui apakah suatu bahan bersifat toksik atau tidak. Pengujian toksisitas adalah pengujian yang dilakukan untuk mengetahui konsentrasi atau dosis minimum yang dapat menyebabkan toksisitas tinggi (dapat berupa kematian) pada bioindikator hewan uji. Metode uji toksisitas dapat dilakukan secara in vitro maupun in vivo. Salah satu metode toksisitas in vitro yang sering digunakan adalah metode Brine Shrimp Letality Test (BSLT). [6].

Dalam uji ini digunakan larva udang Artemia salina Leach sebagai hewan uji dan sifat toksisitasnya dapat diketahui berdasarkan jumlah kematian udang dengan menghitung nilai $\mathrm{LC}_{50}$. Suatu sampel dikatakan memperlihatkan toksisitas terhadap larva udang apabila mempunyai nilai $\mathrm{LC}_{50}<30 \mathrm{ppm}$ memiliki potensi aktivitas sebagai antitumor atau kanker yang bersifat sitotoksik. Nilai $\mathrm{LC}_{50}$ antara $30-200 \mathrm{ppm}$ memiliki potensi sebagai antimikroba. Nilai $\mathrm{LC}_{50}$ lebih dari 200 dan kurang dari 1000 ppm bersifat pestisida [1].

Hasil BSLT menunjukkan nilai LC $_{50}$ fraksi etilasetat daun Nusa Indah adalah 37,15 ppm dan menunjukkan sebagai antimikroba.

Mekanisme kematian larva berhubungan dengan steroid, fenol dan tanin yang dapat menghambat daya makan larva (antifedant) selain itu juga bertindak sebagai stomach poisoning atau racun perut sehingga bila senyawa-senyawa ini masuk ke dalam tubuh larva, alat pencernaannya akan terganggu. Selain itu, senyawa ini menghambat reseptor perasa pada daerah mulut larva. Hal ini mengakibatkan larva gagal mendapatkan stimulus rasa, sehingga tidak mampu mengenali makanannya sehingga larva mati kelaparan.

Tabel 2. Hasil BSLT fraksi etil asetat daun Nusa Indah

\begin{tabular}{cccccccc}
\hline & & & Jumlah & \multicolumn{2}{c}{ Terakumulasi } & $\begin{array}{c}\text { Rasio mati : } \\
\text { total }\end{array}$ & $\begin{array}{c}\text { Mortalitas } \\
(\%)\end{array}$ \\
\cline { 3 - 8 } Konsentrasi & $\begin{array}{c}\text { Log } \\
\text { Konsentrasi }\end{array}$ & Mati & Hidup & $\begin{array}{c}\text { Mati } \\
(\mathrm{x})\end{array}$ & $\begin{array}{c}\text { Hidup } \\
(\mathrm{y})\end{array}$ & $\begin{array}{c}\text { Terakumulasi } \\
\mathrm{x}:(\mathrm{x}+\mathrm{y})\end{array}$ & $\begin{array}{c}\text { Rasio x } \\
100\end{array}$ \\
\hline 10 & 1 & 0 & 30 & 0 & 98 & 0 & 0 \\
20 & 1.30 & 4 & 26 & 4 & 68 & 0.05 & 5 \\
30 & 1.48 & 11 & 19 & 15 & 42 & 0.26 & 26 \\
40 & 1.60 & 15 & 15 & 30 & 23 & 0.57 & 57 \\
50 & 1.69 & 22 & 8 & 52 & 8 & 0.87 & 87 \\
\hline
\end{tabular}




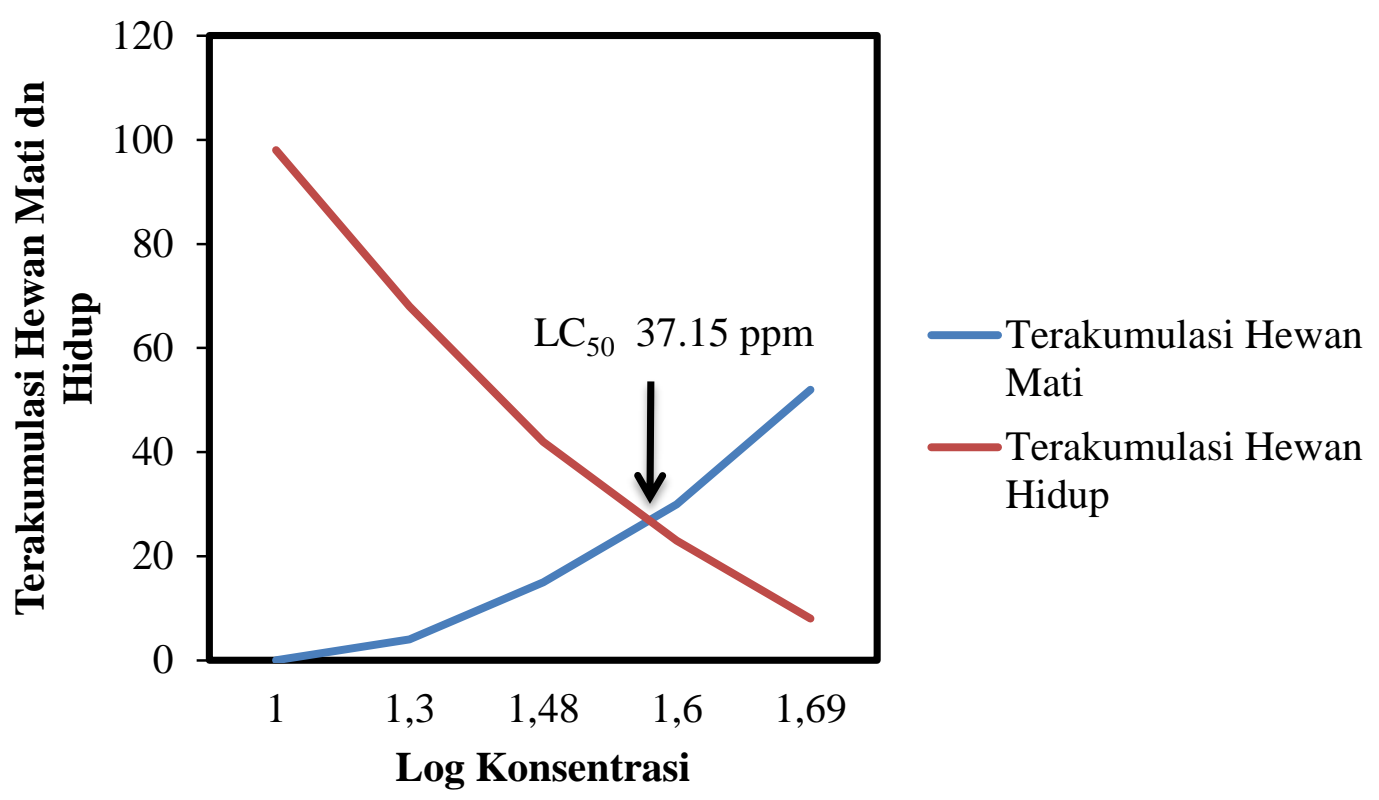

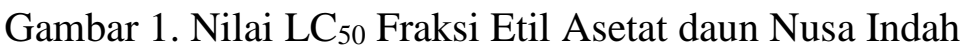

\section{Antioksidan}

Aktivitas antioksidan adalah kemampuan ekstrak dalam menangkap radikal bebas. Untuk mengetahui besarnya persentase peredaman radikal bebas oleh ekstrak maka dilakukan uji aktivitas antioksidan dengan metode peredaman radikal DPPH dengan parameter nilai $\mathrm{IC}_{50}$. Prinsip metode ini adalah senyawa antioksidan dalam sampel akan bereaksi dengan radikal DPPH melalui mekanisme donasi atom hidrogen dan menyebabkan peluruhan warna DPPH [5]. Aktivitas antioksidan daun Nusa Indah dapat dilihat pada Tabel 3.

Berdasarkan Tabel 3 di atas dapat diketahui bahwa fraksi etil asetat daun Nusa Indah memiliki aktivitas antioksidan yang sangat kuat, hal ini dapat dilihat dari besaran nilai $\mathrm{IC}_{50}$. Suatu senyawa dikatakan sebagai antioksidan jika nilai IC 50 kurang dari 200 ppm dan jika yang diperoleh berkisar antara 200 sampai 1000 ppm, maka zat tersebut kurang aktif namun masih berpotensi sebagai zat antioksidan Semakin rendah nilai IC $_{50}$ mengindikasikan aktivitas yang tinggi. $\mathrm{IC}_{50}$ kurang dari $50 \mathrm{ppm}$ sangat aktif atau kuat, sedangkan jika nilai $\mathrm{IC}_{50}$ berkisar 50 ppm sampai 100 ppm cukup aktif atau sedang, 100 ppm sampai 200 ppm sedikit aktif atau lemah. Jika nilai IC $_{50}$ lebih dari 200 ppm tidak aktif [5].

Hasil dari penentuan nilai $\mathrm{IC}_{50}$ didapat dari persamaan kurva regresi linear dari persentase penghambatan sebagai sumbu y dan konsentrasi antioksidan pada sumbu x yang ditampilkan pada Gambar 2.

Senyawa fenol memiliki mekanisme penangkapan radikal bebas melalui reaksinya dengan gugus $-\mathrm{OH}$ bekerja dengan mekanisme kerja antioksidan sekunder.

Steroid bekerja sebagai antioksidan dengan mekanisme kerja antioksidan primer yaitu mampu mengurangi pembentukan radikal bebas baru dengan cara memutus reaksi berantai dan mengubahnya menjadi produk yang lebih stabil.

Tanin merupakan antioksidan yang dapat menangkal adanya radikal bebas untuk mencegah terjadinya stress oksidatif. 
Tabel 3. Aktivitas antioksidan daun Nusa Indah

\begin{tabular}{cccccccc}
\hline \multicolumn{8}{c}{ Absorbansi DPPH 0.616 } \\
\hline \multirow{2}{*}{$\begin{array}{c}\text { Konsentrasi } \\
\text { Sampel (ppm) }\end{array}$} & \multicolumn{2}{c}{$\begin{array}{c}\text { Absorbansi Sampel } \\
\text { setiap Ulangan }\end{array}$} & Rata-Rata & $\begin{array}{l}\text { \% Aktivitas } \\
\text { Antioksidan }\end{array}$ & $\begin{array}{l}\text { Nilai } \\
\text { IC }_{50}\end{array}$ & Keterangan \\
\cline { 2 - 6 } & I & II & III & & & \\
\hline 3 & 0.492 & 0.486 & 0.481 & 0.486 & 21.10 & & \\
6 & 0.360 & 0.405 & 0.375 & 0.380 & 38.31 & \multirow{2}{*}{ Sangat Kuat } \\
9 & 0.261 & 0.257 & 0.270 & 0.263 & 57.30 & ppm & \\
12 & 0.171 & 0.179 & 0.177 & 0.176 & 71.43 & & \\
15 & 0.095 & 0.083 & 0.092 & 0.090 & 85.39 & & \\
\hline
\end{tabular}

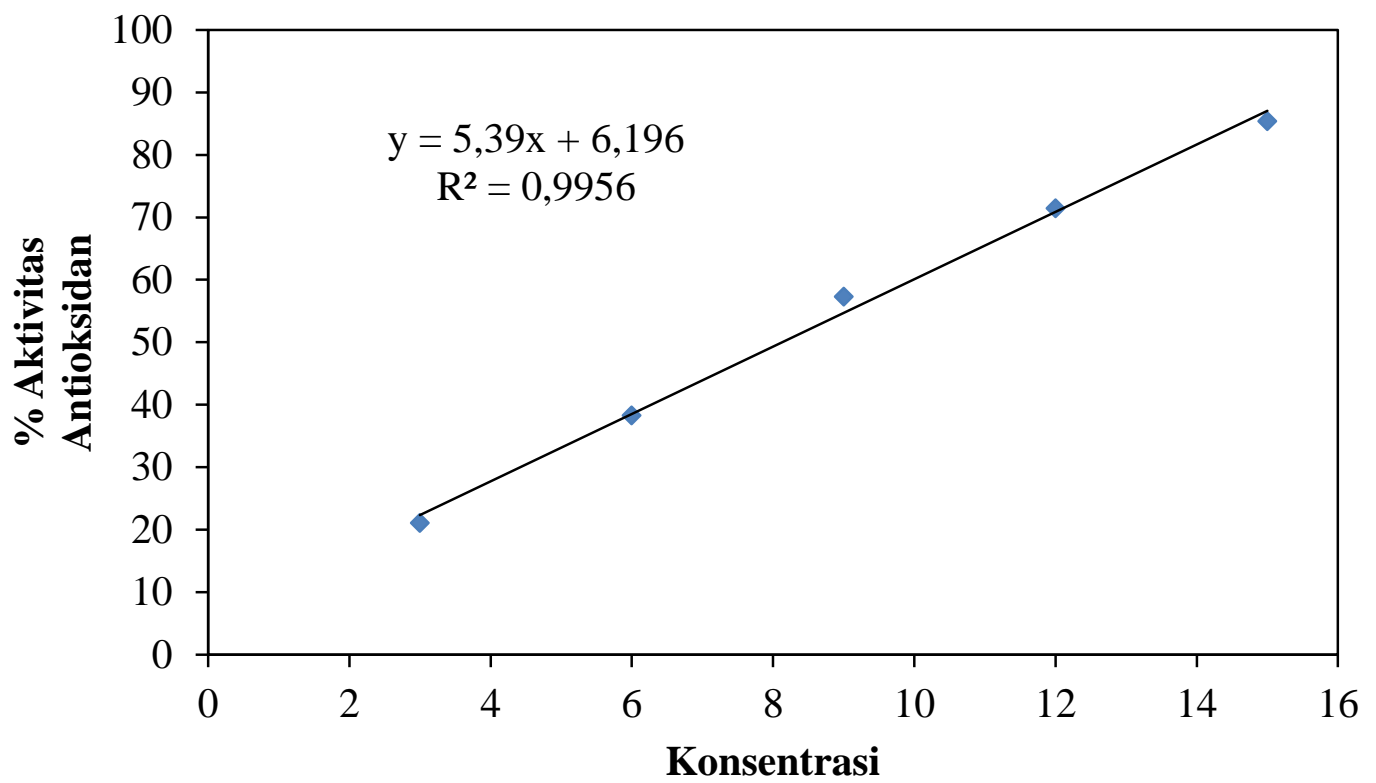

Gambar 2. Nilai IC $_{50}$ Fraksi Etil Asetat daun Nusa Indah

\section{KESIMPULAN}

Hasil BSLT menunjukkan nilai LC S0 $_{50}$ fraksi etilasetat daun Nusa Indah adalah 37,15 ppm. Nilai IC $_{50}$ fraksi etilasetat daun Nusa Indah adalah 8,13 ppm.

\section{DAFTAR PUSTAKA}

Arbiastuti, Yanieta dan Muflihati. 2008. Isolasi dan Uji Aktifitas Kandungan Kimia Bioaktif dari Biji Duku (Lansium domestikum L). J. Penelitian Universitas Tanjungpura Volume : X (2) 
Febrina, Lizma, Rolan Rusli, Fairul Muflihah. 2015. Optimalisasi Ekstraksi dan Uji Metabolit Sekunder Tumbuhan Libo (Ficus Variegate Blume.). Journal of Tropical Pharmacy and Chemistry, 3. (2). 74-81. DOI: https://doi.org/10.25026/jtpc.v3i2.153

Halliwell, B and Gutteridge, J.M.C. 2000. Free Radical in Biology and Medicine. Oxford University Press: New York.

Hariana, Arief. 2013. 262 Tumbuhan Obat dan Khasiatnya. Penebar Swadaya: Jakarta.

Herman. 2013. Aktivitas Antioksidan Beberapa Tumbuhan Obat Kalimantan Timur. Journal of Tropical Pharmacy and Chemistry, 2. (2). 100-104. DOI: https://doi.org/10.25026/jtpc.v2i2.54

Mardany, Modustriarti P., et al. 2016. Skrining Fitokimia dan Uji Aktivitas Sitotoksik dari Tumbuhan Sarang Semut (Myrmecodia beccarii Hook.f.) Asal Kabupaten Merauke. Jurnal Biologi Papua Vol. 8 No. 1.

Kalauw, Syelvia L.N. et al. 2014. Uji BSLT dan Anti Oksidan Ekstrak $n$-Butanol dan Air Pada Ranting Tanaman Sirih Hutan (Piper aduncum .L.). Prosiding Seminar Nasional Kimia.

Vitalia, Nurhawa et al. 2016. Uji Toksisitas Ekstrak Daun Pletekan (Ruellia tuberosa L.) Dengan Menggunakan Metode Brine Shrimp Lethality Test (BSLT). Jurnal Fitofarmaka Indonesia Vol. 3 No.1.

Winarsi, H. 2007. Antioksidan Alami dan Radikal Bebas Edisi V. Kanisius: Yogyakarta 